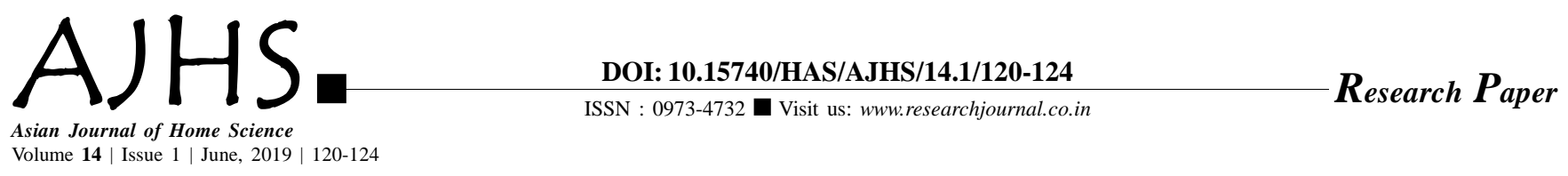

\title{
Impact of vocational training courses on food preservation conducted by Krishi Vigyan Kendras of Punjab
}

\author{
Gagandeep Kaur and Kanwaljit Kaur
}

Received: 01.03.2019; Revised: 25.04.2019; Accepted: 04.05.2019

See end of the paper for authors' affiliations

\section{Gagandeep Kaur}

Department of Extension

Education and Communication Management, Punjab Agricultural University, Ludhiana (Punjab) India

Email: gagandeep.buttar@yahoo .com
ABSTRACT : The study was conducted to assess the impact of vocational training courses on food preservation conducted by Krishi Vigyan Kendras of Punjab. Nine Krishi Vigyan Kendras i.e. Amritsar, Bathinda, Hoshiarpur, Patiala, Fatehgarh Sahib, Mukatsar Sahib, Jalandhar, Moga and Ludhiana were selected to conduct the study. These Krishi Vigyan Kendras had organized twenty three short duration courses on food preservation from year 2011 to 2013. Out of 582 women trainees who had attended these vocational training courses of Krishi Vigyan Kendras, 179 trainees constituted the sample of study. Data were collected through self structured interview schedule. Impact of vocational training was assessed in terms of its adoption status, extent of adoption and level of use of training. Training on Pappad and Vadian, chawanparash and preserves/Murabha had achieved the highest adoption status. Lowest adoption status was observed in sun drying of vegetable, pickle making and preparation of squashes. Adoption status of majority of practices in terms of its use at household level was high. But practices related to recommended quantity of food preservator were either not adopted or discontinued. Extent of adoption of different practices on food preservation training course was also observed high. Only one per cent of trainees had established an enterprise after receiving training and two per cent were using training for income generation purpose. Major constraint for nonestablishment of an enterprise was weak financial position. It can be concluded that awareness regarding financial assistance provided by the government to start an enterprise should be created to trainees.

KEY WORDS: Vocational training, Adoption status, Impact, Extent of adoption

- HOW TO CITE THIS PAPER : Kaur, Gagandeep and Kaur, Kanwaljit (2019). Impact of vocational training courses on food preservation conducted by Krishi Vigyan Kendras of Punjab. Asian J. Home Sci., 14 (1) : 120-124, DOI: 10.15740/HAS/AJHS/14.1/120-124. Copyright@ 2019: Hind Agri-Horticultural Society. 